NBER WORKING PAPER SERIES

\title{
GLOBALIZATION AND INTERNATIONAL COMMODITY TRADE WITH SPECIFIC REFERENCE TO THE WEST AFRICAN COCOA PRODUCERS
}

\author{
Christopher L. Gilbert \\ Panos Varangis \\ Working Paper 9668 \\ http://www.nber.org/papers/w9668 \\ NATIONAL BUREAU OF ECONOMIC RESEARCH \\ 1050 Massachusetts Avenue \\ Cambridge, MA 02138 \\ April 2003
}

This paper is forthcoming in R.E. Baldwin and L.A. Winters eds., Challenges to Gloabilization, NBER (2003). It was prepared for the International Seminar on International Trade (ISIT), Stockholm, 24-25 May 2002. We are grateful to participants at the ISIT conference, and in particular Joshua Aizenman and Bob Baldwin for comments on the presentation of earlier material. The views expressed herein are those of the authors and not necessarily those of the National Bureau of Economic Research.

(C)2003 by Christopher L. Gilbert and Panos Varangis. All rights reserved. Short sections of text not to exceed two paragraphs, may be quoted without explicit permission provided that full credit including Cnotice, is given to the source. 
Globalization and International Commodity Trade with Specific

Reference to the West African Cocoa Producers

Christopher L. Gilbert and Panos Varangis

NBER Working Paper No. 9668

April 2003

JEL No. Q17, F14

\section{$\underline{\text { ABSTRACT }}$}

Liberalization of tropical agricultural markets has brought globalization, in the sense that all producers now face world rather than domestic prices. Producer prices have tended to rise as a share of fob prices as intermediation costs and tax has declined. However, in conjunction with inelastic demand, the downward shift of the aggregate supply curve results in lower world prices. Farmers therefore get a higher share of a lower price. Cocoa is the market where these changes have been most pronounced. The incidence of the liberalization benefits in cocoa is largely on developed country consumers at the expense of the governments of the exporting countries and farmers in nonliberalizing (non-African) countries. Farmers in liberalized African markets are broadly neither better nor worse off.

Christopher L. Gilbert

Vrije Universiteit Amsterdam

De Boelelaan 1105

1081 HV Amsterdam

The Netherlands

cgilbert@feweb.vu.nl
Panos Varangis

ARD

The World Bank

1818 H Street NW

Washington, DC

pvarangis@worldbank.org 


\section{Introduction}

Since the early 1980s, dramatic changes in export commodity markets, shocks associated with price declines, and changing views on the role of the government have ushered in wide-spread market liberalization programs to agricultural commodity markets in Africa. These programs significantly reduced government participation in marketing and pricing of export commodities. Market liberalization entails a greater reliance on markets to direct resource utilization and investment. In the context of this paper, market liberalization refers to steps taken toward opening domestic and export markets to competition and toward putting in place public and private institutions consistent with and supportive of private markets. ${ }^{1}$

Critics have raised several concerns about the trend to market liberalization. These include the claim that, while liberalization may make sense for an individual exporting country, when several do it simultaneously they increase exports so strongly that they drive down the prices and revenues they receive from exporting and make themselves worse off. Critics also sometimes argue that liberalization has opened farmers up to price and income fluctuations from which they were previously insulated. Economic theory makes clear that all these problems can arise in particular circumstances, so the real questions are empirical. This chapter provides some answers by exploring one case of primary commodity liberalization in some detail cocoa in West Africa. We show that such distributional issues are of first-order importance to the political debate about globalization.

We need to distinguish between liberalization and globalization. Liberalization is the move to market-determined prices from what was previously a regulated regime. One of the implications of liberalization is that the prices received by farmers in different producing countries move together much more closely than prior to liberalization. It also implies that markets in each producing country are more closely inter-connected than previously with the result that decisions taken in one country affect farmers in each of the other producing countries. We refer to these two aspects of liberalization as globalization. Governments decided (or agreed)

1 Bates (1989) notes that markets adjust automatically, leaving the realignment of government institutions as the real task of structural adjustment. 
to liberalize, while globalization was a consequence of these decisions and not an objective in itself.

For commodity markets, liberalization has meant reducing government involvement in marketing and in production, increasing participation of the private sector in these activities and reducing distortions in commodity prices, especially producer prices. Measures implemented to achieve these goals vary but often they have included the elimination of government marketing agencies, the introduction of competition in marketing, the elimination of administered prices, reduction in explicit and implicit taxes, and the privatization of government-owned assets.

Events triggering market liberalization were not independent of broader political and economic changes in most countries and the consequences of liberalization are often linked as well. However, issues related to the approaches and effects of general and agricultural market liberalization have been discussed elsewhere and receive minimal treatment here (for full treatment see World Bank 1994; Engberg-Pedersen et al. 1996; Mosley et al. 1991). Instead, our purpose is to discuss market liberalization in the specific context of cocoa, and particularly to examine the impact of liberalization on the prices obtained by west African cocoa producers, and the revenues they receive. We also empirically estimate supply and demand elasticities for west African producers and use these to simulate the welfare effects of liberalization on west African cocoa producers, non-African producers and world consumers of cocoa products, and the revenue loss to west African governments.

West Africa accounts for nearly two-thirds of the world's cocoa production. Before the late 1980s, west African cocoa was entirely produced and marketed under government controlled systems. However, starting in the late 1980s and continuing into the 1990s all four of West Africa's largest cocoa producing countries, Cameroon, Côte d'Ivoire, Ghana and Nigeria, together with Togo (a smaller cocoa producer), took steps towards liberalizing their cocoa markets. Much of the aim of the reforms was to improve efficiency by reducing domestic marketing costs, provide a higher pass-through of international prices to producer prices, and increase the producer share of the fob price. According to Akiyama, et al (2001), market liberalization in cocoa had a positive effect on producer prices relative to fob prices, and also to production. 
The claimed increase in production raises the question whether liberalization by the West African producers may, despite the relative rise in producer prices, have led to a net loss in total welfare in these countries as the result of the likely negative impact of the production increase on the world cocoa price. To the extent that thus occurred, the incidence of the benefits from liberalization will have been on cocoa consumers, most of whom are in the developed market economies. Developed country governments already have to counter the charge of hypocrisy ("incoherence" in official parlance) in that they advocate market liberalization in the Third World while maintaining regulated and subsidized domestic agricultural markets. If it is also the case that the incidence of the benefits of liberalization is significantly enjoyed by developed country consumers, it may be difficult to avoid the impression that these governments and the international agencies are guilty of pursuing self-interested policies in the developing world.

This is an instance of the well-known adding-up problem. Here, the problem arises as the welfare effects of unilateral liberalization by an individual and relatively small cocoa producer will differ from, and be lower than, the welfare effects of multilateral liberalization by a group of producing countries which collectively make constitute a large proportion of the world market. In the former case, it may is reasonable to take the world price as unaffected by the liberalization, while in the latter case, this assumption would be absurd. The adding up problem has generated a large literature starting from Johnson $(1953,1958)$ and Bhagwati (1958) and, more recently, Krishna (1993). Schiff (1994) states that countries with market power in commodities should proceed with trade and domestic liberalization and should apply optimal export taxes to those commodities in which they have market power. Akiyama and Larson (1994) argued as a practical matter it is not feasible to design a regional commodity production and trade policy for cocoa producing countries in Africa mainly because of the difficulty of equitably distributing the benefits of such policy.

In a related literature, Evenson (2002) looks at the impact of technology on agricultural prices. He finds that there are significant costs to countries that do not adopt new technology because they suffer from low prices and lack of production growth. New technologies have led to lower prices but countries that have adopted new technologies have benefited from expanded production. Liberalization has lowered marketing costs and margins in the same way as has 
technological advance and its impact on production should therefore also be similar. Countries cannot afford to be left behind in this process.

The choice of cocoa to examine these questions is deliberate and advised.

- Along with coffee, rice, sugar and wheat, cocoa has historically been one of the most heavily regulated commodity markets.

- In common with coffee, but unlike sugar and wheat, it is almost entirely a developing country commodity. ${ }^{2}$

- Unlike coffee, regulation was predominantly at a national rather than an international level. ${ }^{3}$

- The liberalization process can be fairly cleanly dated in the cocoa market. The rice, sugar and wheat markets remain less fully liberalized.

It is our belief that the concentration of production in four west African countries, all of which had heavily regulated internal markets, makes it likely that the adverse (from the point of view of the liberalizing countries) adding-up effects of liberalization will be both larger and more clear than in any other major market.

The present paper is structured as follows. Section 2 discusses the economics of liberalization while section 3 highlights certain aspects of the world cocoa market, particularly in relation to market liberalization. In section 4 we look at the direct consequences of liberalization and globalization in the world cocoa market. Section 5 presents a world cocoa market model and section 6 indicates the beneficiaries of market liberalization based on the results of the model simulations. Section 7 concludes.

\section{The Economics of Market Liberalization}

The market liberalization programs enjoined on developing country governments in the markets for tropical commodities had two complementary objectives. The first was to ensure that farmers would receive a higher proportion of world prices than had been the case in the pre-liberalization period. This often involved a reduction in (implicit or explicit) export tax rates. The second objective was to align incentives with world prices, both for farmers and more generally in the

2 The sole OECD cocoa production is a very small quantity in Australia.

3 See Gilbert $(1987,1996)$ for a discussion if international commodity market regulation in cocoa and coffee. 
marketing chain, in the expectation that production and marketing would be more efficient. It was hoped that these incentives would increase both production and revenues in the liberalizing economies. This price realignment process involved an ending of previous inter-annual, intraannual and intra-national (interregional) price stabilization arrangements, and paralleled the simultaneous abandonment of attempts to stabilize international prices though commodity agreements. At the same time, previously monopsonistic marketing systems were opened up to competition. See Akiyama et al (2001) and Gilbert and ter Wengel (2001) for a summary of these developments.

Market liberalization is part of the globalization phenomenon in that producers of tropical commodities now react in a more or less uniform manner to a common world price whereas previously domestic and international marketing arrangements often shielded then from the world price.

The practical effects of market liberalization are often both complicated and controversial. We will take it that liberalization has indeed increased the farmer's share of the port (fob) price, both because of reduced taxation and reductions in marketing cost. Varangis and Schreiber (2001) discuss the cocoa outcomes. The balance between these two effects, the first of which is a transfer and the second a pure efficiency gain, undoubtedly varies across commodities and also across countries for the same commodity. ${ }^{4}$

The globalization aspects of market liberalization align domestic prices more closely with the volatile world cocoa price, and the reigning back of the marketing boards and caisses de stabilisation (see section 3) reduces governments' capacities to offset this volatility. The consequence is that farmers will, in general, be more exposed to commodity price variability. This imposes additional costs on them, both through the costs of uncertainty and also from the direct costs of low prices - see Gilbert (2002). We make the standard assumption that developing

4 There are also arguments, which we do not explore in this paper, that market liberalization may have resulted in a deterioration in crop quality - see Gilbert and Tollens (2002). 
country farmers lack access to either credit or to risk management instruments. They are therefore obliged to self-insure through diversification. ${ }^{5}$

Proponents of liberalization hoped and intended that, by ensuring that farmers would get a higher share of fob prices, that they would be better off. The farmers themselves note that in practice they have been rewarded by a higher share of a lower price. They often go on to argue that they are no better off and perhaps worse off than before liberalization. Of course, because prices are volatile, these complaints are more often heard in low price than in high price years. It is also possible to respond with the counterfactual argument that, because of continued productivity advance in tropical agriculture, prices would have fallen relative to the prices of manufactures in the absence of liberalization so that, even if it is true that farmers are no better off than previously, they are at least better off than they would have been in the absence of liberalization. In our experience, it is difficult to persuade developing country farmers that this is more than self-justifying sophistry. Furthermore, farmers believe that the fall in tropical commodity prices has in fact in large measure been induced by the liberalization process itself.

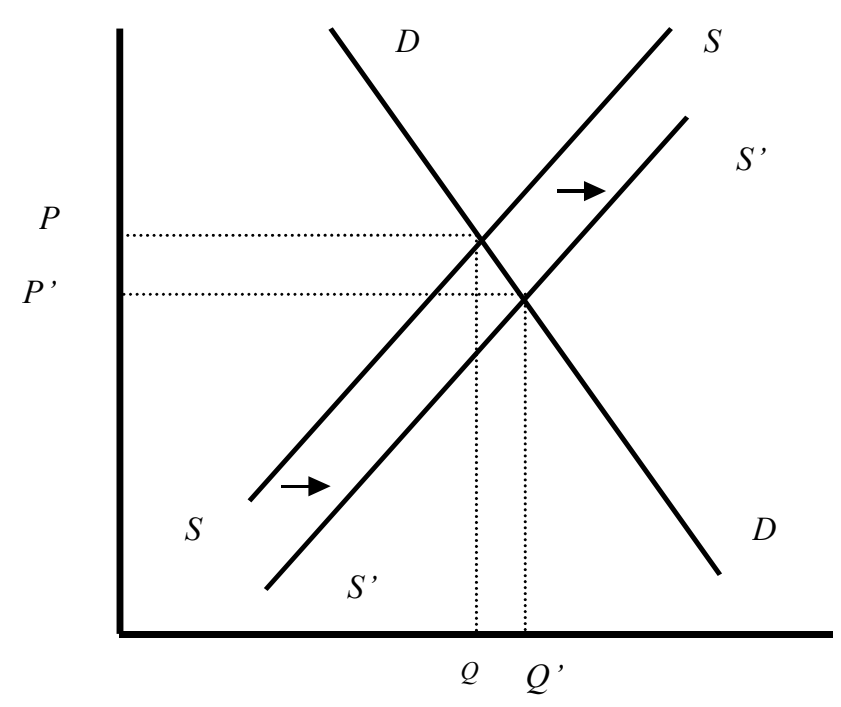

Figure 1: The Price Impact of Market Liberalization

5 It might be suggested that, even if farmers lack access to credit, they are always able to save in good times and hence dissave in bad times - see Paxson (1993). However, the almost complete absence of rural banks in west Africa makes it difficult even to save. 
It is easy to see why this should be the case. Holding the world price constant, to the extent that market liberalization has increased the price obtained by farmers they will be willing to supply more at that world price level. They can do this either by exploiting existing capital more intensively (by increased application of effort and purchased inputs) or by expanding the area under cultivation. The supply curve from the liberalizing country therefore shifts right and, so long as the supply of the liberalizing country is not negligible compared to world supply, the aggregate supply function will also shift right. This will induce a fall in the world price which will be larger to the extent that (i) a significant fraction of world production is affected in this way and (ii) the demand curve is inelastic - see Figure 1.

This is a standard instance of the old Johnson $(1953,1958)$ and Bhagwati (1958) "adding up" problem. If one confines attention to market liberalization in a single "small" country, it is legitimate to hold the world price constant, at least as a first approximation. However, if one considers liberalization either in a major producer of the commodity or in a significant group of individually small producers, it will be important to take into account the effect on the world price. The implication is that the sum of the benefits to each of the individual liberalizers, under the assumption the world price does not change, will exceed the actual total welfare effects in the liberalizing countries, taking into account the decline in the world cocoa price. Proponents of liberalization have always admitted the principle of this argument but have proceeded on the basis that the adding up effect is of the second order of importance. Instead, the anti-liberalizers may be interpreted as suggesting that the adding up costs are of a comparable order to the original liberalization benefits, and indeed that they may even exceed these benefits.

It is straightforward to obtain a first order approximation for the size of the adding up effect. ${ }^{6}$ Write the international price of the commodity as $P$, and write the domestic producer price in producing country $j$ as $p_{\mathrm{j}}(j=1, \ldots, n)$. Write production in country $j$ as $Q_{\mathrm{j}}=Q^{\mathrm{j}}\left(p_{\mathrm{j}}, \sigma_{\mathrm{j}}\right)$, where we have supposed that production depends not only on the price received by farmers in $j$ but also on the variability of the price, measured by the log standard deviation of domestic

6 The estimates reported in section 6 are based on exact numerical solution of the model. 
prices. The aggregate (world) demand for the commodity is $D(P)$. Suppose the effects of liberalization on the level of the domestic price in country $j$ can be represented as

$$
\Delta \ln p_{j}=\Delta \ln P+\delta_{j}
$$

This equation states that the direct effect of liberalization is to raise the producer price in the country by the proportion $\delta_{\mathrm{j}}$, but there may also be an indirect effect through the (negative) impact of liberalization on the world price $P .{ }^{7}$ Making the reasonable assumption that liberalization has no effect on desired inventory holdings, market clearing requires

$$
\sum_{j=1}^{n} Q^{j}\left(p_{j}, \sigma_{j}\right)=D(P)
$$

Differentiating and approximating by finite differences

$$
\sum_{j=1}^{n} \frac{\partial Q^{j}}{\partial p_{j} / p_{j}}\left(\Delta \ln P+\delta_{j}\right)+\sum_{j=1}^{n} \frac{\partial Q_{j}}{\partial \sigma_{j}} \Delta \sigma_{j}=\frac{\partial D}{\partial P / P} \Delta \ln P
$$

Write the supply elasticity in country $j$ as $\varepsilon_{j}=\frac{\partial \ln Q_{j}}{\partial \ln p_{j}}$, the volatility semi-elasticity as $\theta_{j}=-\frac{\partial \ln Q_{j}}{\partial \sigma_{j}}$ and the aggregate price elasticity of demand as $\eta=-\frac{\partial \ln D}{\partial \ln P}$, and define the production share of country $j$ as $\omega_{j}=\frac{Q_{j}}{\sum_{i=1}^{n} Q_{i}}$. Using this notation, we may approximate equation (3) to give

$$
\Delta \ln P=-\frac{\sum_{i=1}^{n} \omega_{i} \varepsilon_{i} \delta_{i}-\sum_{i=1}^{n} \omega_{i} \theta_{i} \Delta \sigma_{i}}{\eta+\sum_{i=1}^{n} \omega_{i} \varepsilon_{i}}
$$

Consider the simple case in which supply elasticities and volatility semi-elasticities are equal in all producing countries. Suppose further that there are $m$ liberalizing countries (aggregate share

7 It is possible that this volatility effect may be sufficiently large as to dominate the impact of the higher price on production. This would result in an increase in the world price - see Newbery and Stiglitz (1981, pp.327-9). Kanbur (1984) shows that in the case of cocoa, under plausible assumptions, the risk benefits from stabilization are lower than the transfer benefits. 
$\alpha$ ) each of which sees producer prices rise relative to the world price by a uniform amount of $\delta$ and price volatility rise by the uniform amount $v$. By implication, there are $n-m$ non-liberalizers with share 1- $\alpha$. Equation (4) simplifies to

$$
\Delta \ln P=-\alpha \frac{\varepsilon \delta-\theta v}{\eta+\varepsilon}
$$

and the domestic price in liberalizing country $j$ rises by

$$
\Delta \ln p_{j}=\frac{[\eta+(1-\alpha) \varepsilon]}{\eta+\varepsilon} \delta+\frac{\alpha \theta v}{\eta+\varepsilon}
$$

Consider first the case in which production is unaffected by changes in price variability $(\theta=0)$. A unilateral liberalization by a small producer will be associated with a value of $\alpha$ close to zero. The impact on the world price will be negligible and the incidence of the producer price will be entirely on the producers in the liberalizing country. However, the larger the share of the liberalizing countries, and the higher the supply elasticities relative to the demand elasticity, the greater the dissipation of the effects of liberalization through decline in the world price. The limiting case is if demand is completely inelastic $(\eta=0)$ and the entire set of producers liberalize $(\alpha=1)$. In this case $\Delta \ln p_{\mathrm{j}}=0(j=1, \ldots, n)$ and $\Delta \ln P=-\delta$ implying that liberalization results in a transfer from producing country governments to consumers with farmers unaffected. Farmers are never made worse off by liberalization, but they may not be much better off. Consumers will always be better off and producing country governments worse off. Depending on the welfare weight given to government, producing countries as a whole may well be worse off.

Allowing a production response to increased volatility reduces the impact of globalization on the world price, and hence raises local prices, ceteris paribus, but also opens the possibility that liberalization may worsen the position of farmers.

\section{The World Cocoa Market and Cocoa Market Liberalization}

Cocoa is a tropical tree crop commodity. Furthermore, it is par excellence the west African crop. Côte d'Ivoire is the single largest producer and exporter of cocoa, and together Côte d'Ivoire, Ghana, Nigeria and Cameroon are responsible for over $60 \%$ of world production see Figure 2 which gives averages for the nineteen nineties. In west Africa, cocoa is almost 
entirely a smallholder crop. All four of the major west African cocoa-producing countries had regulated marketing structures which they inherited from their colonial administrations. The major non-African cocoa exporters are Indonesia (the second most important exporter) followed by Malaysia and Brazil where, for different reasons, production has been declining.

The standard crop marketing structure adopted in countries with a British colonial history was of monopoly-monopsony marketing boards. In the ex-French colonies ownership of the crop remained with the private sector, but the state intervened by setting producer and export prices, by issuing export licences, and by stabilizing prices through a caisse de stabilisation. In cocoa, Ghana and Nigeria operated marketing boards, while Côte d'Ivoire operates a caisse system. Cameroon, which combines ex-British and ex-French colonial territories, adopted a hybrid model. Marketing boards and caisses were never a feature of non-African cocoa producing countries.

Marketing board and caisse structures were justified in terms of price stabilization (interyear and intra-year), quality assurance, and provision of services to farmers (subsidized input purchase, extension). These systems came under significant pressure over the nineteen eighties and nineties, in particular from the two major donor institutions - the World Bank and the European Union (EU), which was involved as the consequence of the STABEX program established under the succession of Lomé Treaties with the ACP (Asian, Caribbean and Pacific) group of countries. 
Figure 2: Cocoa Production 1990-91 - 1999-2000

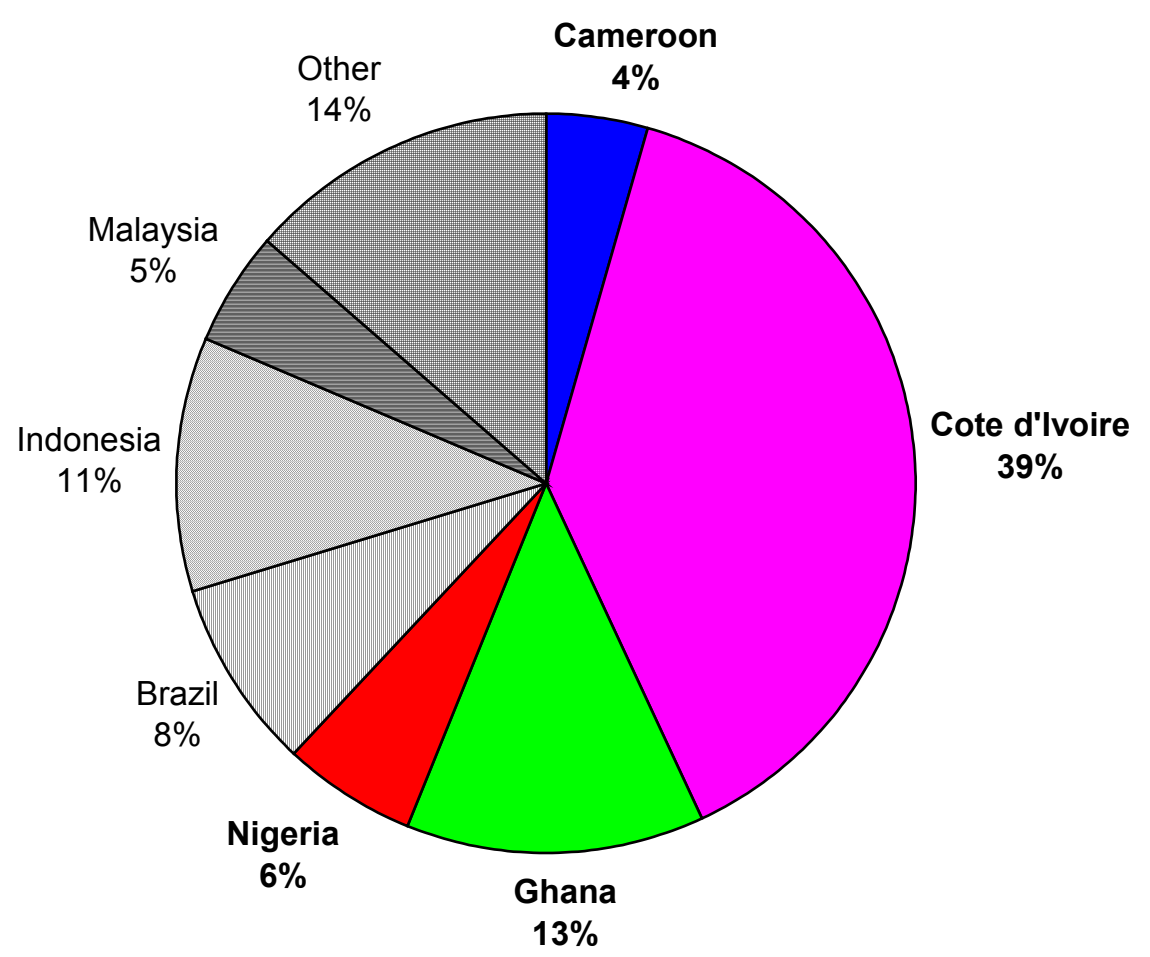

Donor pressure is often seen as having been ideologically motivated, and there is no doubt an element of truth in this, although it is difficult to argue that the European Union has always exhibited and over-riding general commitment to liberalized agricultural markets. In any case, other factors were of greater importance:

- Primary commodity prices were at historically low levels in the second half of the nineteen eighties. The cocoa price fell more or less steadily from its 1977 peak to a low in the early nineties, and has subsequently only recovered to a modest extent. Stabilization agencies which attempted to maintain cocoa producer prices at levels which had been feasible in the seventies and early eighties consequently found themselves in financial problems. In certain countries, these were exacerbated by the fact that accumulated stabilization surpluses from earlier years had typically been "invested" in illiquid and poorly performing assets. The 
result was that a number of boards and caisses became technically insolvent.

- Marketing board and caisse arrangements were viewed as non-transparent. Accounts were often late and opaque. It was difficult to distinguish taxes, which were potentially available to finance government expenditure, from marketing costs.

- The stabilization agencies became large organizations, often exercising significant political power, and absorbing a substantial share of countries' cocoa export earnings. Cocoa marketing costs were therefore significantly higher in African producing countries than elsewhere, and there was reason to suppose that this involved a significant element of rent extraction. For example, Williams (1985) wrote of the Nigerian agricultural marketing boards shortly before their abolition in 1986, "They have replaced the European firms at the apex of the buying system and shaped it to serve the needs of ruling parties, governments and the Northern aristocracy to expand and consolidate their networks of patronage."

- Farmers have the residual claim on crop revenues. Falling world prices in conjunction with an unchanged marketing wedge exerted significant downward pressure on farm incomes.

- Stabilization also proved to be expensive for farmers. For them, stabilization often meant lower overall prices in exchange of stable prices. McIntire \& Varangis (1999) evaluated the trade off between stability and level of prices for the case of Côte d'Ivoire. They found that the benefits of stable prices did not compensate for the overall lower level of prices paid to the Ivorian cocoa farmers.

Donor institutions balked at refinancing the insolvent stabilization agencies, perhaps in part because they preferred free markets, but also because it was clear that the major beneficiaries of refinancing would be the stabilization agencies themselves, and the political causes they espoused. Furthermore, non-transparency made it difficult to account for uses of funds provided. Farmers were seen by the donors as being poorly represented in the African political process, in particular in countries where regimes are less than fully democratic. Liberalization therefore came to be seen as a means of reducing marketing costs and raising farmers' share of the fob price.

The first African cocoa liberalization was that of Nigeria in 1986. Although the World Bank had argued that the Nigerian agricultural marketing boards were ineffective and had sought 
their abolition as part of a structural adjustment program, the Nigerian government rejected that program but decided to abolish the marketing boards unilaterally. The World Bank would have preferred agricultural liberalization to be sequenced after foreign exchange liberalization, which was not implemented at that time. There was little preparation for liberalization and the process is regarded as having been unnecessarily chaotic - see Gilbert (1997).

Cameroon, the smallest of the major African producers, was next to move. This liberalization took place in stages starting in 1989 and concluding in 1995 - see Gilbert (1997) for details. The major impetus to liberalization was the insolvency of the stabilization agency, the Office National du Commericialisation des Produits de Base (ONCPB) which had responsibility for coffee as well as cocoa. The EU made replacement of the ONCPB by an organization with a more limited role (the Office National du Café et du Cacao, ONCC) a condition of STABEX financial support and required a sharp reduction in the price offered to farmers. The World Bank was never significantly involved with the Cameroon cocoa sector. Unlike the Nigerian liberalization, the Cameroonian reforms were never fully "owned" by the government or the Cameroonian media which has consistently seen them as imposed by the donors. But despite the questionable ownership of reforms in Cameroon and problems in Nigeria, cocoa farmers in these two countries benefited significantly as prices paid to them rose substantially following the reforms.

Both Nigeria and Cameroon may be seen as small producers - see Figure 1. This cannot be said of Côte d'Ivoire. Ivorian cocoa policy was administered through the Caisse de Stabilisation et du Soutien des Prix des Produits Agricoles, normally known simply as the Caistab. Prior to 1989, Ivorian cocoa prices were set at very similar levels to those in Cameroon, partly reflecting the common currency, but possibly also on the basis of common external advice. Caistab therefore experienced similar financial problems on the late nineteen eighties to those of the Cameroonian ONCPB. However the EU was prepared to offer greater assistance to the Ivorians. A sequence of piecemeal reforms was made through the nineteen nineties with the objective of increasing the transparency of the process by which exporters bid for "déblocage" (ie permission to export). Supposedly complete liberalization came in 1999, largely as the consequence of World Bank insistence, although in practice there has been considerable back- 
tracking on the spirit of those commitments. As in the Cameroonian case, reform ownership remains problematic.

It is notable that the 1999 Ivorian liberalization coincided with a sharp fall in cocoa prices, attributed by many farmers and also by some government officials and their advisors to the liberalization process. Our view, which coincides with that of the cocoa industry, is that this price fall was due to lack of growth in cocoa consumption completely unrelated to the liberalization process. ${ }^{8}$ In any case, the fall in price led to significant civil disobedience and put pressure on the government to assist cocoa farmers. Cocoa prices have recovered sharply in 2001 and 2002 as consumption rose in the context of weak production reflecting neglect of cocoa trees during the previous low price years.

Ghana is the remaining major African cocoa producer. Currently, it has only liberalized partially and tentatively. The Ghana Cocoa Board, generally referred to as Cocobod, historically enjoyed monopsony-monopoly power. Licenced private buyers are now permitted to operate, but they are still required to sell to Cocobod and are in principle required to buy from farmers at the same regulated price. Ghanaian farmers are however now obtaining a significantly higher share of the fob price than during the nineteen eighties, reflecting a partial retreat from the inter-annual stabilization objective, some reduction in cocoa taxation, and a sharp fall in the Cocobod establishment.

Ghanaian cocoa sells at a significant premium to cocoa from other origins, in part because of a good fat content but most importantly because of the reliability and rigour of Cocobod quality controls. These controls depend in large measure on Cocobod's monopolymonopsony powers. Although there is an issue of the size of the Ghanaian premium in relation to the cost of producing cocoa of this quality, ${ }^{9}$ the Ghanaians are clearly correct to worry that liberalization could result in an erosion of this premium.

\footnotetext{
${ }^{8}$ Cocoa grindings were effectively constant in $1998-99$ (2.77m tons against $2.78 \mathrm{~m}$ tons on $1997-98$ while production rose $4 \frac{1}{2} \%$ over the same period (from $2.61 \mathrm{~m}$ tons to $2.80 \mathrm{~m}$ tons). Source: International Cocoa Organization, Quarterly Bulletin of Cocoa Statistics, 26(3), 1999-2000.
} 


\section{The Direct Impact of Liberalization and Globalization}

The complexity and diversity of the west African cocoa market liberalization process makes it difficult to identify the appropriate dates for before-after comparisons. Liberalization is a legal act and can therefore be dated precisely - 1986-87 for Nigeria, 1989-91 and 1995 for Cameroon and 1999 for Côte d'Ivoire with Ghana still to fully liberalize. By contract, globalization is a process which is partially consequential on liberalization, as in Nigeria in Cameroon, but which may also anticipate liberalization if, as in Côte d'Ivoire and Ghana, administered prices are brought increasingly into line with the world price.

Figure 3: Deflated Cocoa Producer Prices and Deflated ICCO Indicator Price (1985=100)

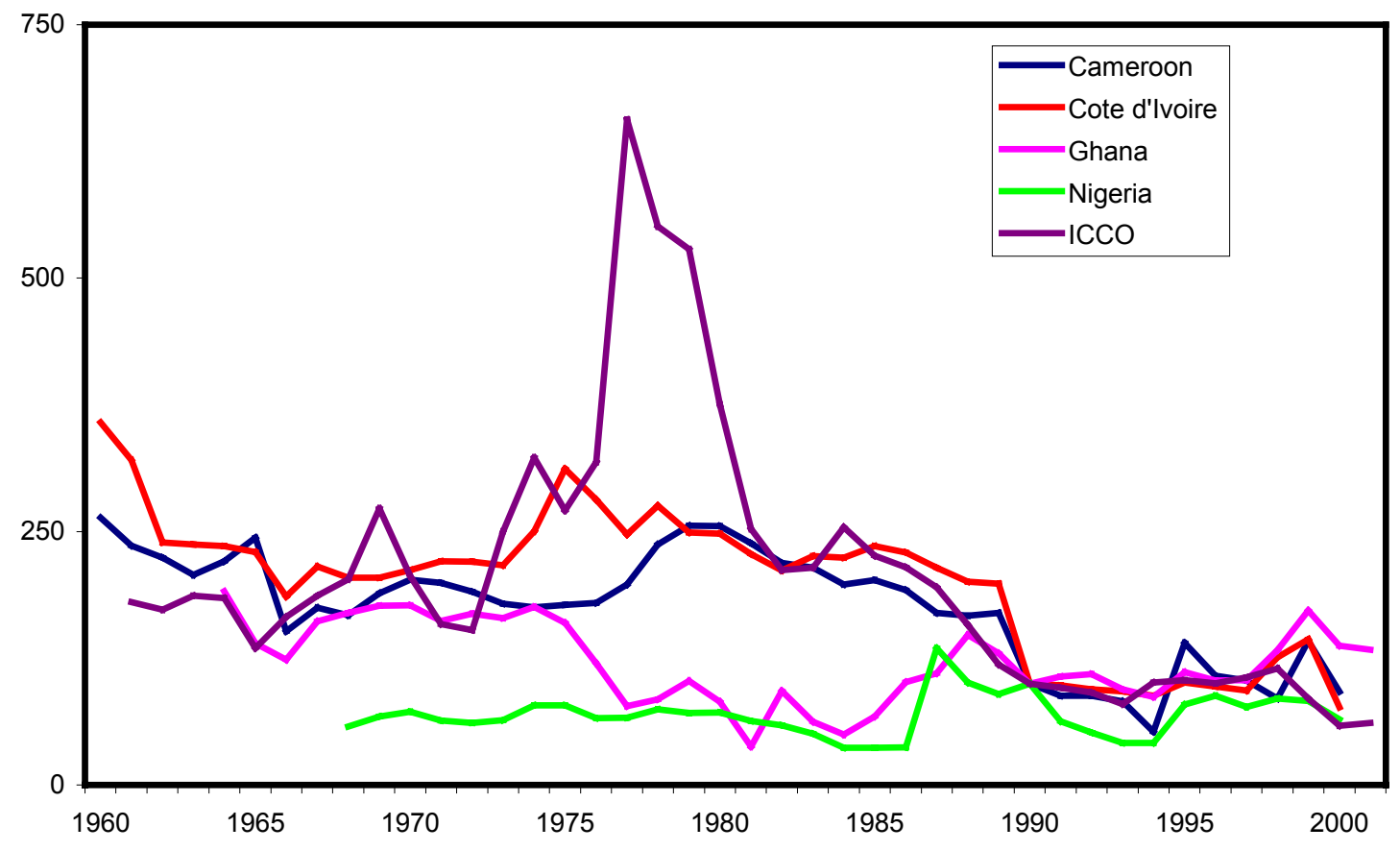

\footnotetext{
${ }^{9}$ The major cost arises from the diversion of sub-export quality beans to domestic processing for which purpose they are sold at what is believed to be a significant discount to world prices.
} 
Figure 3 charts producer prices in the four west African countries and also the ICCO indicator price which we interpret as the world price. ${ }^{10}$ It is apparent that these five prices have moved much more closely together since 1990 than in earlier years. This visual impression is broadly confirmed by the correlations shown in Table 1 . The bold face correlations above the diagonal give correlations between the proportionate price changes in the four producing countries over crop years 1968-69 to 1985-86 (the year prior to the Nigerian liberalization). The italicized correlations beneath the diagonal give the same correlations over crop years 1989-90 to 1998-99. The table also includes the correlations with changes in the ICCO indicator price lagged one year. The table shows the prices in Cameroon, Côte d'Ivoire and Ghana (although Nigeria to a much lesser extent) moving much more closely together after 1990 than before 1986. The leading principal component of the four price change series accounts for $43.9 \%$ of the price variation prior to liberalization and $69.8 \%$ after liberalization. All four prices also move more closely with the ICCO price in the post-liberalization period.

\begin{tabular}{|l|ccccc|}
\hline \multicolumn{7}{|c|}{ Table 1 } \\
Price Correlations 1968-69 to 1985-86 (above diagonal) and \\
1989-90 to 1998-99 (beneath diagonal)
\end{tabular}

On the basis of these figures, we conclude that the west African cocoa producers globalized, in the sense of moving to a common world cocoa price, from the start of the nineteen nineties. The Nigerian liberalization was three years prior to this, and the institutional liberalizations in Cameroon and Côte d'Ivoire came over the course of the following decade.

\footnotetext{
${ }^{10}$ The four producer prices are in domestic currency units and are deflated by national Consumer Price Indices. The ICCO price is in US dollars and is deflated by the US CPI. (Source: IMF, International Financial Statistics). The five prices are measured as indices normalized at 1990 $=100$. There is, however, no implication that the five 1990 prices are equal.
} 
However, crucially, the start of the nineteen nineties saw the move away from inter-annual price stabilization in both these two countries (under EU pressure) and also in Ghana. In the calculations we report in section 6, we therefore regard the period up to (and including) 1985-86 as pre-globalization and the period from 1989-90 to date as post-globalization.

The principal objective of liberalization was to raise the share of the fob price received by farmers. There are two possible approaches to the problem of measuring this impact:

- Take time averages of the shares of the producer prices, converted into dollars, in the world price before and after liberalization. However, this exercise is complicated by the complicated non-market exchange rate regimes operated by Ghana and Nigeria over the periods of interest.

- Use point estimates of the shares of producer prices in fob port prices, both measured in local currency. This procedure gives a clearer comparison but necessarily introduces a degree of arbitrariness in the dates selected for the comparison - it is apparent from Figure 1 that the extent to which the various producer prices were divorced from the world price varies considerably over time.

We adopt the second of these procedures. Table 2 brings together some estimates of the effects of liberalization on the farmer's share of the fob price. These figures allow comparison of the four liberalizing origins in west Africa with Brazil, Indonesia and Malaysia which have no history of internally regulated cocoa markets. Figures relating to liberalized markets are italicized. There is broad agreement between the Ruf and de Milly (1990) figures for 1989 and those taken from the World Bank, LMC International (a commodity consulting firm) ${ }^{11}$ and Gilbert and Tollens (1999). This comparison highlights the sharp jump in the Cameroonian share after liberalization but also the steady increase in the Ivorian share prior to the formal liberalization in the 1999-2000 season.

11 Private communication. 


\begin{tabular}{|l|c|c|c|c|}
\hline \multicolumn{5}{|c|}{ Table 2 } \\
\hline & $\begin{array}{c}\text { Ruf \& de } \\
\text { Milly (1990) }\end{array}$ & World Bank & LMC & $\begin{array}{c}\text { Gilbert \& } \\
\text { Tollens (1999) }\end{array}$ \\
\cline { 2 - 5 } & 1989 & $1994-95$ & 1996 & $1998-99$ \\
\hline Cameroon & $41 \%$ & $71 \%$ & $75 \%$ & $73 \%$ \\
Côte d'Ivoire & $48 \%$ & $48 \%$ & $47 \%$ & $63 \%$ \\
Ghana & $52 \%$ & $49 \%$ & $56 \%$ & $56 \%$ \\
Nigeria & $74 \%$ & $72 \%$ & $88 \%$ & $90 \%$ \\
Brazil & $79 \%$ & $72 \%$ & $72 \%$ & n.a. \\
Indonesia & $87 \%$ & $78 \%$ & $78 \%$ & $88 \%$ \\
Malaysia & $72 \%$ & $94 \%$ & $91 \%$ & n.a. \\
\hline Average: liberalized & $78.0 \%$ & $77.4 \%$ & $80.8 \%$ & $84.0 \%$ \\
Average: non-liberalized & $47.0 \%$ & $48.5 \%$ & $51.2 \%$ & $59.7 \%$ \\
Liberalization effect & $31.0 \%$ & $28.9 \%$ & $29.6 \%$ & $24.3 \%$ \\
\hline
\end{tabular}

On the basis of these figures, we take the pre-liberalization shares in Cameroon and Côte d'Ivoire to be those given by Ruf and de Milly (1990) and the post-liberalization shares to be equal to the $81 \%$ average reported by LMC for 1996 . Ghana and Nigeria pose greater problems. In Ghana, which has yet to fully liberalize, we lack a post-liberalization share while for Nigeria, which liberalized before the Ruf and de Milly (1990) survey, we lack a pre-liberalization estimate. Furthermore, it is apparent from Figure 1 that Ghana had already commenced raising its producer price share prior to 1989 . We take a starting value for both countries of $47 \%$, the non-liberalized average from Ruf and de Milly (1990) and see the Nigerian share rising by $41 \%$ to the LMC figure of $88 \%$, with the Ghanaian share rising by $34 \%$ to the LMC liberalized average of $81 \%{ }^{12}$ These estimates are clearly at best orders of magnitude and should be treated as such. The impact of rises in the producer's share of the fob price on actual producer prices will depend on the impact on the world price.

These increases in the farmer's share of the world price result from two separate effects. The first is cost reductions arising out of more efficient intermediation. The second is the reduction in taxation. One might in principle regard the administrative expenses of the

12 The very high LMC estimate of the share of the Nigerian producer price in the fob price reflects the lack of dependence of the Nigerian government on taxes on agricultural exports. We would expect Ghana to continue to tax cocoa export revenues even after full liberalization. Note that because intermediation 
stabilization agencies as either taxation or as an intermediation cost item - we follow the latter approach. Figure 4, which is based on statistics taken from Gilbert and Tollens (1999), shows the dramatic differences between tax levels in the two non-liberalized countries (Côte d'Ivoire and Ghana) compared with that in the liberalized economies. On the basis of these statistics, we estimate that $75 \%$ of the increase in the producers' share in the liberalization process arises from reduced taxation.

Figure 4

Taxes and Marketing Costs as Shares of the Producer Price, 1998-99

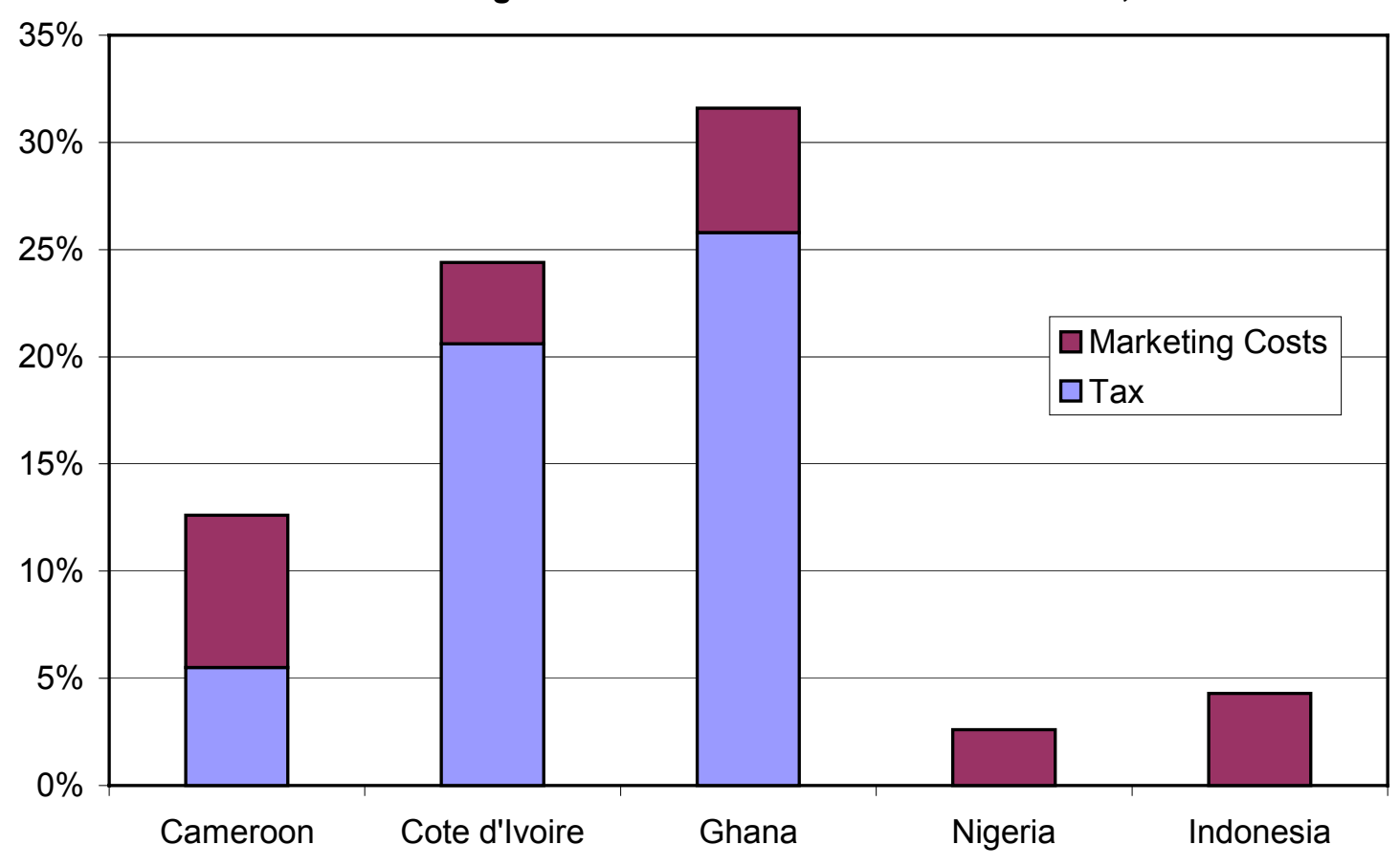

That estimate is conjectural. Reductions in intermediation costs are important in the welfare analysis we perform in section 6 because these may be interpreted as efficiency gains while reductions in taxation generate transfers. Relatively little information is available on the scale of these benefits. Gilbert and Tollens (1999), who interviewed new and established cocoa

costs are largely independent of the cocoa price, the producer share, which is a residual, will be positively correlated with the price. 
exporters in Cameroon, estimated that intermediation costs had fallen by $5 \%$ (relative to the producer price) in the three years following full liberalization. ${ }^{13}$

\section{Figure 5}

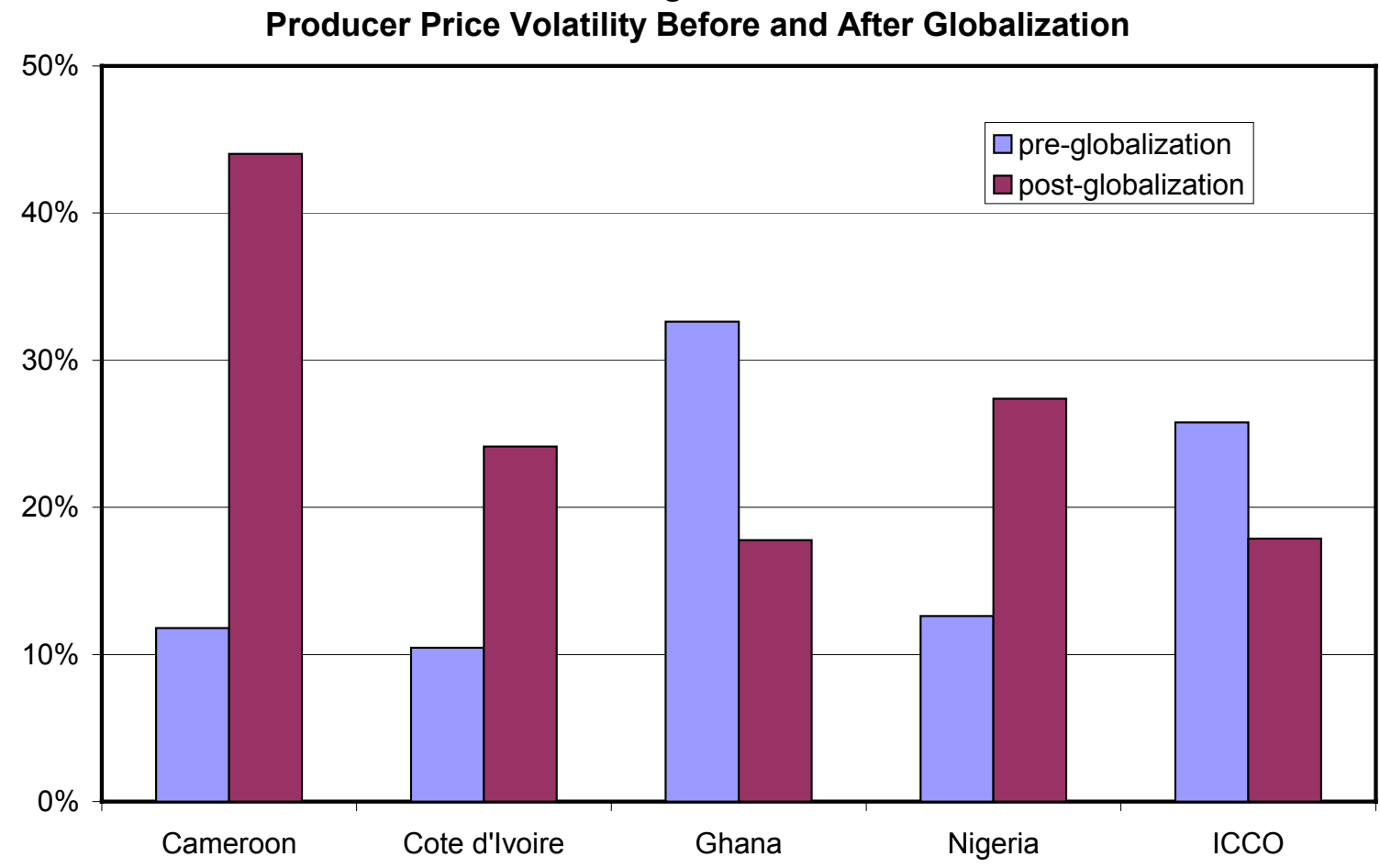

Globalization will also have affected, and generally increased, the variability of the prices received by farmers. Figure 5 shows the unconditional inter-annual logarithmic standard deviations of the four (deflated) producer prices before and after globalization. ${ }^{14}$ Farmers in Cameroon have experienced the largest increase in price variability, a rise of $32 \%$ from $12 \%$ to 44\%. Instead, Côte d'Ivoire and Nigeria have seen more modest rises, while volatility in Ghana has actually fallen. This last, paradoxical, finding is the consequence of the lack of success of Cocobod in its declared stabilization objective during the nineteen eighties when sharp movements in inflation in the supposedly stabilized domestic price becoming, in real terms, more

13 They attributed these differences to the fact that newer exporters utilized less capital and made greater use of specialized intermediaries (such as transportation companies). Despite this, Cameroonian intermediation costs remained (and remain) high. 
variable than the world price. Note that, except in Ghana where the nominal producer price continues to be fixed for the entire crop-year, the figures tabulated in Figure 4 may underestimate the increase in variability experienced by farmers since liberalization has also increased intraannual price variability.

Figure 4 also reports the variability of the world (ICCO Indicator) price over the same period. The modest decline in world price variability implies that the rises in Cameroon, Côte d'Ivoire and Nigeria cannot be attributable to any greater variability in the post-globalization world price.

\section{A Model of the World Cocoa Market}

Because our interest is in the four major west African producing countries which have liberalized their cocoa sectors, our strategy is to model production in these countries in detail but to embed these equations in what is otherwise a highly aggregated world model. A benefit of this approach is that we do not need to make gratuitous assumptions about other aspects of the cocoa market. A cost is that highly stylized modeling of consumption and non-African production may distort our results.

For each of the four origins $(j=1, . ., 4)$ we consider, we model production $Q_{\mathrm{jt}}$ in period $t$ as a linear function of a quadratic time trend, current and lagged expected prices and price volatility.

$$
\ln Q_{j t}=\beta_{j 0}+\beta_{j 1} t+\beta_{j 2} \frac{t^{2}}{100}+\beta_{j 3} E_{t-1} \ln P_{j t}+\beta_{j 4} E_{t-2} \ln P_{j t-1}+\beta_{j 5} \sigma_{j t}+u_{j t}
$$

The quadratic trend is required to account for the declines and subsequent rises in production in Ghana and Nigeria. It may be argued that these changes were in fact determined by the movements in producer prices in those countries, but if so, these effects arise form the cumulative effects of prices over a long period and are not easily modelled in terms of simple lag distributions. In any case, part of these two declines and the subsequent reversals reflect changes

14 Cameroon and Côte d'Ivoire: $1960-61$ to $1988-89$, 1990-91 to 1998-99; Ghana 1964-65 to 1988-89, 1989-90 to 1999-2000; Nigeria 1968-69 to 1985-86, 1988-89 to 1998-99; ICCO 1962-63 to 1988-89, $1989-90$ to $2000-01$. 
in infrastructure investment, the provision of extension and other factors which cannot be directly related to price levels.

The expected producer prices $\mathrm{E}_{\mathrm{t}-1} \ln P_{\mathrm{jt}}$ and $\mathrm{E}_{\mathrm{t}-2} \ln P_{\mathrm{jt}-1}$ in equation (7) are generated as the one period predictions from estimated trend-augmented first order autoregressions

$$
\ln P_{j t}=\gamma_{0}+\gamma_{1} \ln P_{j, t-1}+v_{j t}
$$

Equation (8) is estimated separately for each country for the pre-globalization and postglobalization periods. This specification supposes that farmers form price expectations rationally on the basis of the limited information set consisting of the local price history, and without any need to learn the price processes. ${ }^{15}$ In principle, one would expect only the current period expectations $\mathrm{E}_{\mathrm{t}-1} \ln P_{\mathrm{jt}}$ to explain production but in practice the lagged expectation $\mathrm{E}_{\mathrm{t}-1} \ln P_{\mathrm{jt}-1}$ is also required.

The price volatility $\sigma_{\mathrm{jt}}$ is the unconditional standard deviation of proportionate price changes in country $j$ estimated separately for the pre- and post-globalization periods. ${ }^{16}$ The expected sign of the coefficients $\beta_{\mathrm{j} 5}$ is negative as farmers self-insure by diversifying effort away from the risky crop.

The estimated price autoregressions (8) are given in Table 3 (see end of paper). The divide between the pre-globalization sample I and the post-globalization sample II is taken as between the 1988-89 and 1989-90 crop years for Cameroon, Côte d'Ivoire and Ghana, and between the 1986-87 and 1987-88 crop years for Nigeria. The trend terms are dropped as insignificant from the Cameroonian and Ivorian price autoregression equations (real producer prices in these two countries dropped sharply in 1989 but not within the two samples). Chow

15 We explored two alternative specifications for the price expectations variables. The first was to allow the pre-liberalization expectations to be formed on the basis of actual announced nominal producer prices in conjunction with a rational expectation of the rate of inflation. This specification gave significantly inferior fit in the production equations. The second alternative was to allow price expectations to be formed on the basis of the lagged world (ie ICCO Indicator) price in addition to the lagged domestic price. This gave qualitatively similar results for the estimated production equations to the specification employed, marginally inferior in terms of fit for Cameroon, Côte d'Ivoire and Ghana, and marginally superior for Nigeria.

16 An alternative would have been to use an $\mathrm{ARCH}$ or GARCH conditional volatility. The only price equation (9) which showed evidence of $\mathrm{ARCH}$ effects was the pre-liberalization equation for Cameroon. 
tests give clear rejections of sample homogeneity for Cameroon and Côte d'Ivoire but not for Ghana, where full liberalization has yet to take place, or (more surprisingly) for Nigeria. ${ }^{17}$

Estimates of the production equations (7) are given in Table 4. The first set of estimates for each origin employs OLS. The coefficient $\beta_{23}$ in the Ivorian equation, where the unrestricted estimate was negative, was set to zero. The significance of the individual price coefficients for the remaining three origins is not high in every case, but the joint significance of the two coefficients, examined by the standard F test, is high. Estimated supply elasticities $\beta_{\mathrm{j} 3}+\beta_{\mathrm{j} 4}$ vary from 0.26 (Côte d'Ivoire) to 0.71 (Ghana).

These single equation estimates suffer from two problems:

- They result in different supply elasticities for the different origins. It is plausible to argue that these differing estimated responses reflect sampling error rather than genuine differences in farmers' behavior.

- They do not permit estimation of the volatility effects (since the volatility variable for a single country is indistinguishable from a shift dummy at the sample break).

We address these two problems by re-estimating the model as a system using FIML. ${ }^{18}$ The system estimates allow us to impose the restriction of equal supply elasticities across all four producing countries:

$$
\beta_{j 3}+\beta_{j 4}=\beta_{13}+\beta_{14} \quad(j=2,3,4)
$$

and also to estimate the volatility coefficients by imposing the restrictions

$$
\beta_{j 5}=\beta_{15} \quad(j=2,3,4)
$$

The estimated equations using the FIML procedure are given in the second set of country columns in Table 3 . The (uniform) estimated supply elasticity is 0.43 , and the volatility response is estimated as -0.24 , in both cases the coefficients being significantly different from zero. A

17 The differences between the two samples are more evident in the set of estimates (not reported) based on the specification which also includes the lagged world price. These estimates show the burden of the dependence shifting from the lagged domestic price in sample I to the lagged world price in sample II. 18 A third problem is that the standard errors in the reported OLS regressions will suffer from generated regressor bias - see Pagan (1984). We do not correct for this because we will be primarily interested in the FIML estimates. 
standard likelihood ratio test establishes that coefficient restrictions in (9) and (10) are acceptable. $^{19}$

Ideally, we should also estimate supply elasticities for the remainder of the world. Unfortunately, we have not been able to obtain producer price series of sufficient length for the other major origins to estimate realistic equations. This is in part a consequence of the fact that, in a liberalized regime, domestic prices are not uniform and that there is seldom any official interest in collecting information on prices actually paid. Pursing the alternative track of specifying equations in terms of the world (ICCO Indicator) price failed to generate a production elasticity which was either economically or statistically significant. Since it would be unreasonable to suppose that non-African cocoa production is unresponsive to prices, we have chosen to suppose the estimated non-African elasticity is equal to that reported above for the major African origins.

We also require a demand elasticity estimate. Apparent consumption of cocoa is referred to in the trade as grindings. We estimate a standard logarithmic partial adjustment demand function relating aggregate world grindings $G_{\mathrm{t}}$ to the GDP of the industrialized countries $\left(G D P_{\mathrm{t}}\right)$, a linear time trend and the current dollar world price deflated by the US CPI $\left(P W_{\mathrm{t}}\right)$. The resulting estimates only conform moderately well with theory - there is evidence of a continuing shift in taste towards cocoa consumption at around $2 \%$ per annum, but no evidence that this is related to income, at least as measured by GDP. ${ }^{20}$ The estimated price elasticity is relatively small at 0.19 . This may seem surprising but it should be noted that cocoa now only makes up between $5 \%$ and $10 \%$ by value of a chocolate bar, and less of a chocolate-covered confectionary product. Estimation is by instrumental variables, ${ }^{21}$ treating the current world price as endogenous. The estimated equation is

19 The most problematic restriction is that relating to the Ivorian price elasticity $\beta_{24}$. One may have some confidence that the estimated volatility coefficient is indeed measuring a volatility effect from the fact that volatility has declined in one the four origins (Ghana) in the period since 1989, while it has increased in the remaining three origins.

20 The $t$ statistic on the variable $\ln G D P_{t}$, dropped from the equation reported as (12), was 0.19 .

$21 \mathrm{We}$ use as instruments the exogenous variables included in the production equations. These are the current and lagged expected producer prices in the four west African origins (only the lagged expected price for Côte d'Ivoire since the current price was dropped as incorrectly signed from the Ivorian production equation), and the quadratic trend. 


$$
\begin{aligned}
& \ln G_{t}={ }_{(3.73)}^{4.1567}+{ }_{(3.88)}^{.0100} t+{ }_{(3.50)}^{0.4812} \ln G_{t-1}+{ }_{(1.71)}^{0.5991} \Delta \ln G D P_{t}- \\
& \text { Sample }: 1969-70 \text { to } 1998-99 \\
& \text { S.e. }=0.0266 \\
& \text { Instrument validity } \chi^{2}(7)=3.04 \quad[88.1 \%]
\end{aligned}
$$

In section 6 , we use the estimated elasticity from this equation in conjunction with the supply elasticity and volatility coefficient from the FIML estimates reported in Table 3 to evaluate the effects of globalization of the cocoa market.

\section{Incidence - Who Benefited?}

We consider two scenarios:

- unilateral liberalization-globalization by each country considered separately;

- joint liberalization by all four origins.

As discussed in section 3, the actual liberalization process was less clear-cut than this and indeed is still incomplete, and globalization has to some extent anticipated full liberalization.

Table 5 collects together the parameter values which we use in the incidence calculations. We so this in conjunction with equation (4) to estimate the effects of unilateral and joint (multilateral) liberalization, which are reported in Table 6. The small country assumption appears reasonable for Cameroon and Nigeria, where liberalization is seen as having depressed the world price by $3 \%$ in each case; but not for Côte d'Ivoire, where liberalization is seen as reducing the world price by $10 \%$. Ghana, where liberalization would push the world price down by $5 \%$, is intermediate. It is notable that Nigeria and Cameroon were the first major African cocoa producers to liberalize and that liberalization was resisted in Ghana and Côte d'Ivoire where the spillover effects onto the world price are larger. The impact of increased volatility on the world price is seen as small but non-negligible. Turning to the multilateral liberalization, the world price is seen as falling by $20 \%$ in conjunction with a weighted average rise in African producer prices of $76 \%$.

The global welfare impact of these changes may be analyzed by reference to Figure 6 which has the world price on its vertical axes. The first panel (a) shows the non-African supply curve $S^{\mathrm{R}}$, while the second panel (b) displays the pre-liberalization African supply curve $S^{\mathrm{A}}$ 
which is above the marginal cost curve $\mathrm{C}^{\mathrm{A}}$ by the taxation wedge. The producer price is $P^{\mathrm{A}}$. The initial world price is $P$ but this falls to $P^{\prime}$ after liberalization.

We see liberalization as shifting the marginal cost curve in the liberalizing economy down to $\mathrm{CC}^{\mathrm{A}}$ through cost reductions and as eliminating the tax wedge. This shifts after liberalization supply function to $S S^{\mathrm{A}}$ which is coincident the new marginal cost schedule $\mathrm{CC}^{\mathrm{A}}$. The producer price is shown as rising to $P^{\mathrm{A},} \cdot{ }^{22}$ World supply $S^{\mathrm{W}}$ is the horizontal sum of $S^{\mathrm{A}}$ and $S^{\mathrm{R}}\left(\mathrm{Q}^{\mathrm{W}}=\mathrm{Q}^{\mathrm{A}}+\mathrm{Q}^{\mathrm{R}}\right)$, which becomes $S S^{\mathrm{W}}$ after liberalization - see panel (c). The world demand curve is $D^{\mathrm{W}}$. Production in the non-liberalizing economies falls from $Q^{\mathrm{R}}$ to $Q^{\mathrm{R}}$, and consumption rises from $Q^{\mathrm{W}}$ to $Q^{\mathrm{W}}$, Ignoring the complicating factor of price volatility, welfare changes are as follows:

Farmers in non-liberalizing economies: $\quad-\mathrm{A}$

Governments of liberalizing economies: $\quad-(\mathrm{C}+\mathrm{D}+\mathrm{E}+\mathrm{F})$

Farmers in liberalizing economies: $\quad \mathrm{E}+\mathrm{F}+\mathrm{G}+\mathrm{H}+\mathrm{I}+\mathrm{J}$

Consumers: $\quad \mathrm{K}+\mathrm{L}+\mathrm{M}$

Provided we count $\$ 1$ to an African government as equivalent to $\$ 1$ to an African farmer, the net benefit to the liberalizing country is $(\mathrm{G}+\mathrm{H})+(\mathrm{I}+\mathrm{J})-(\mathrm{C}+\mathrm{D})$. The country benefits in net terms so long as the efficiency gains $(I+J)$ exceed the transfer to foreign consumers $(C+D)$. On the same assumption, and noting that $\mathrm{A}+\mathrm{C}=\mathrm{K}$ and $\mathrm{B}+\mathrm{D}=\mathrm{L}$, the net world benefit is $B+(G+H)+(I+J)+M$. Triangle B is the efficiency gain from substituting low cost cocoa in the liberalizing economies for higher cost cocoa in the rest of the world; rectangle $\mathrm{G}+\mathrm{H}$ is the cost reduction on the original quantity $\mathrm{Q}^{\mathrm{A}}$ in the liberalizing economies; ${ }^{23}$ triangles $\mathrm{I}+\mathrm{J}$ represent the efficiency gain from cost reduction in the liberalizing countries; triangle $\mathrm{M}$ is additional consumer surplus arising from the lower world price.

We evaluate these quantities using the parameters displayed in Table 5 and in relation to average price and production levels for the period 1985-86 to 1989-1990, ie prior to the impact of all the liberalizations except that of Nigeria. The effect of liberalization-globalization on the world price is obtained by numerical solution of the production and consumption equations

22 If the cost reduction is large relative to the tax reduction, $P^{\mathrm{A}}$, can be beneath $P^{\mathrm{A}}$.

23 One might argue that $\mathrm{G}+\mathrm{H}$ is not entirely a benefit to the liberalizing economy if the resources liberated by the cost reduction do not find alternative use. 
through the market clearing identity. The results of this exercise are given in Tables 7 (unilateral, country-by-country liberalization) and Table 8 (multilateral liberalization and globalization by the four African cocoa-producing countries). Table 9 gives a break-down of the estimated efficiency gains.

Considering first the unilateral liberalization calculations (Table 7), the major effect is a transfer of resources from government to farmers. Farmers benefit most in Côte d'Ivoire (nearly $\$ 500 \mathrm{~m}$ per annum), followed by Ghana (nearly $\$ 225 \mathrm{~m}$ per annum) and then Cameroon and Nigeria (around $\$ 125 \mathrm{~m}$ per annum). These benefits are in proportion to the size of the respective producing sectors. However, they are offset by governmental losses of tax revenue which are of the same order of magnitude, so the net dollar benefits to the countries are much smaller - a little less than \$40m on an annual basis for each of Cameroon, Côte d'Ivoire and Nigeria, and a little more than $\$ 55 \mathrm{~m}$ for Ghana. ${ }^{24}$ The Ivorian benefits are relatively modest since the producer price is seen as rising by less than in the other origins (the pre-liberalization level was higher), and the price rise is dissipated to a greater extent through a fall in the world price. Consumers, who are predominantly in the developed economies, are seen as major beneficiaries, in particular from an Ivorian liberalization, while non-liberalizing producers lose heavily. Total world benefits are modest and in broad proportion to sectoral size - around $\$ 45 \mathrm{~m}$ annually from Cameroonian and Nigerian liberalizations, \$80m from Ghanaian liberalization and \$175m from Ivorian liberalization. They are dominated by the transfer benefits, both within the liberalizing economy (from the government to farmers) and from non-liberalizing producers to consumers.

Table 8 gives the estimated results of a multilateral liberalization. It is important to note that this does not represent the actual experience to date in that both Côte d'Ivoire and Ghana have both only partially liberalized marketing and maintain export taxes. The price shocks we list in Table 5 are substantially greater than those observed to date in these two countries. The estimates given in Table 8 therefore relate to a hypothetical full liberalization and not to the actual observed events. An analysis of the impact of the actual liberalizations would be considerably more complicated and would require a fully specified econometric model.

24 If one were to take the view that $\$ 1$ to a government is worth less than $\$ 1$ to a smallholder farmer, the producing countries would benefit more substantially. 
The estimates in Table 8 show that although farmers would have benefited in each of Cameroon, Ghana and Nigeria, these benefits are almost exactly offset by the losses of governmental tax revenue with the result that the countries as whole would be slightly worse off. In Côte d'Ivoire, the revenue loss substantially exceeds the benefit to farmers so the net loss in unambiguous. As in the unilateral exercise, to the extent that government cocoa revenues were spent on wasteful activities, the countries, taken as wholes, will have benefited in welfare terms even in this case. This must be a judgmental matter. Non-liberalizing countries also are seen as losing revenues, and their farmers would have been worse off. The major beneficiaries would have been consumers in the developed market economies who have benefited of the order of $\$ 725 \mathrm{~m}$ per annum, around $20 \%$ of their cocoa expenditures.

The analysis of the net efficiency gains reported in Table 9 shows that cost reductions consequential on liberalization are the major source of net benefit. We have supposed that 25\% of the increase in the producer price share may be attributed to cost reductions, but we acknowledge that this figure is highly conjectural. Allocational gains in the liberalizing economies are the next largest item. These arise from elimination of the tax wedge between the producer price and marginal production costs. Allocational gains in consuming and nonliberalizing producer countries are small, reflecting low elasticities. The increased volatility arising out of globalization imposes only small costs, except in Côte d'Ivoire.

These exercises assume that liberalizing governments totally eliminate export taxes. The unilateral liberalization exercise reported in Table 7 shows that Cameroon, Ghana and Nigeria all benefit from increasing production and would therefore lose revenues from export taxes. In Côte d'Ivoire, the net benefit is small in relation to production implying that revenues would be broadly unaffected by restricting production. The results of the multilateral exercise reported in Table 8 further show that the four African producers would all benefit substantially from a coordinated restriction of production. This must be subject to the qualifications that prolonged periods of high prices may provoke new production in other countries (including countries which are not currently significant cocoa exporters), and that the conclusion will not follow if government revenues are less highly valued than farmers' incomes). However, our model, which 
is specified as having isoelastic demand and supply functions, is not well-suited to the calculation of optimal export taxes. ${ }^{25}$

\section{Conclusions}

Donor agents and the developed country governments have exerted considerable pressure on African producers of tropical export crops to liberalize their internal marketing systems for these products. They have also pressed for the elimination or reigning back of intertemporal and interregional stabilization schemes which were seen as responsible for fiscal excess and manifest waste. The major objective of these liberalization programs has been to ensure that farmers obtain a higher share in the fob prices for which the crop is sold at the ports.

Globalization of these markets is a direct consequence of liberalization - the prices in the now liberalized markets move substantially more closely together than did the pre-liberalized prices so the world price has become the effective pricing basis in the producing as well as the consuming countries. Globalization has two unsought consequences for producing countries

- the prices received by farmers have become more volatile (except in Ghana where the nominal price stabilization had been counter-productive); and

- the effects of one country's actions in the market impact much more directly than previously on farmers in other producing countries.

This second aspect of globalization is the cause of the "adding-up" problem. A cost-reducing market liberalization in a small producing country raises the share of the world price obtained by farmers, and has a negligible effect on the world price itself. However, if a country with a large share of the world market liberalizes, this will shift the world supply curve to the right and, in conjunction with highly inelastic demand, will depress the world price. Farmers will then find that they obtain a larger share of a lower price. The same is true if one considers multilateral liberalization in a large group of individually small producers.

Cocoa is produced entirely in developing countries and largely in west Africa where a system of internal market regulation inherited from colonial governments prevailed until the late nineteen eighties. In our view, these unintended consequences of globalization are likely to be

25 The model implies that, with isoelastic supply and demand functions, and with identical supply 
more apparent in the cocoa market than in any other commodity market. The first African producers to liberalize their internal cocoa marketing systems were Nigeria in 1986 and Cameroon in 1989-95, both of which had small shares in world exports. Adding up effects were therefore unimportant. In 1999, after a long period of pressure, the donors pushed Côte d'Ivoire, the largest producer with one third of world production, into reluctant liberalization. Ghana, which is also a significant producer, still maintains significant controls. If both these producers fully liberalize their markets, the impact on the world price will be significant. Our calculations indicate that the world price would fall in total by around one third of the rise in producer prices calculated on a constant world price basis. This figure reflects the inelasticity of demand and the high market share of the African producers.

Despite the projected fall in the world cocoa price, African farmers do benefit from liberalization, so in that sense the liberalization programs achieve their intended objective. However, these benefits are largely the consequence of a transfer from governments to farmers. The net dollar benefit to the country is positive for a country which liberalizes unilaterally, but the depressing effect on the world price is such that these benefits become negative if all four African cocoa-producing countries liberalize. For this reason, consumers, most of whom live in the developed market economies, turn out to be the major beneficiaries from lower cocoa prices. The scale of this benefit is substantial. The losers are non-African farmers and the governments (and hence the taxpayers) of the African producing countries. The overall efficiency gains to the world are dominated by cost reductions consequent on liberalization, but it is difficult to be confident about the size of these gains.

One reaction to these results would be to argue that producing countries are better advised not to liberalize their agricultural export sectors, and there are many who have taken this position. We regard this view as ill-advised. First, the policy is not obviously feasible since individual producing countries each do have an incentive to liberalize. (In cocoa, this incentive is relatively small for Côte d'Ivoire). The result is a classic Prisoners' Dilemma in which the cooperative non-liberalization equilibrium is not sustainable. But even if the African producers were able to devise an enforcement mechanism to support the non-liberalization equilibrium,

elasticities, all producers would have the same export share at a Cournot taxation equilibrium. 
they would be unable to prevent increased production elsewhere, including from counties which are currently not major cocoa exporters. Furthermore, to the extent that liberalization does significantly reduce production and/or intermediation costs, and we have discussed some evidence that suggest this is the case, non-liberalizing producers will find that any competitive advantage they currently possess will be steadily eliminated.

The development agencies have tended to see liberalization as a means of redistributing resources back to farmers. We have shown, however, that the incidence of the long run benefits of liberalization is predominantly on developed country consumers. It is therefore essential that liberalization should be accompanied by policies which attempt to redress the unfavorable redistributive effects arising from global liberalization.

Our thesis is not about market liberalization per se, but about the global impact of multilateral liberalizations by a group of commodity producing countries responsible for a large share of the world market. Liberalization benefits each country taken individually, but, with inelastic demand, multilateral liberalization shifts the benefits away from the producers and towards the consumers. At the country level, primary-producing developing countries will feel that they have been cheated if, collectively, they do not receive a significant share of the benefits. Political support for liberalization will depend on the distribution of the gains both within the producing countries themselves and globally. Governments need to apply complementary policies to accompany liberalization and the international agencies should be prepared to advise and assist in this process.

Clearly, one case study is insufficient to allow generalizations about globalization even in the primary sector. Furthermore, we have focused on cocoa as presenting what is possibly the most extreme cases of an adverse distributional impact. We hope that our analysis and results will shed light on the globalization process affecting all primary commodity markets and provide a benchmark against which other commodity markets and countries might be compared. 


\begin{tabular}{|c|c|c|c|c|c|c|}
\hline \multirow{5}{*}{$\frac{2}{6}$} & 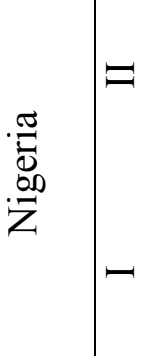 & 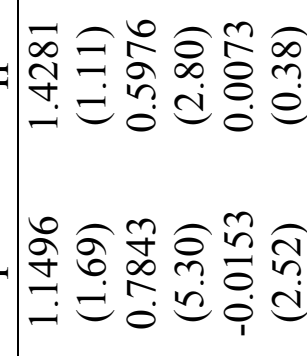 & 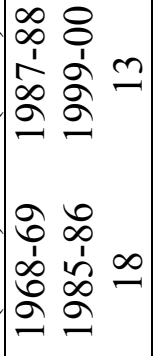 & 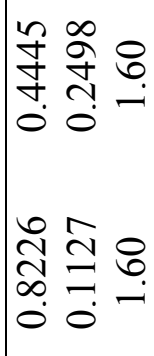 & 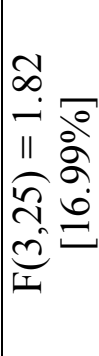 & 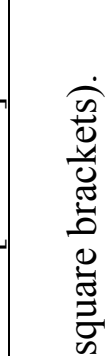 \\
\hline & 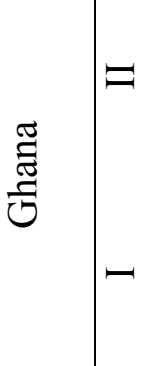 & 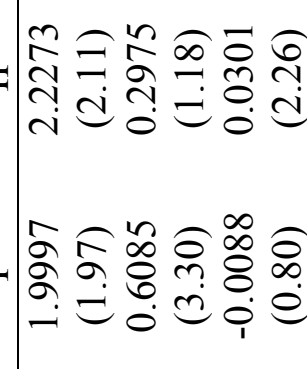 & $\mid \begin{array}{lll}8 & 0 \\
1 & 0 \\
1 & 1 & v \\
\infty & 8 & -1 \\
0 & 0 & 0 \\
- & 1 \\
n & 0 \\
0 & \infty \\
1 & 1 & 1 \\
0 & \infty & 0 \\
0 & 0 & 0\end{array}$ & 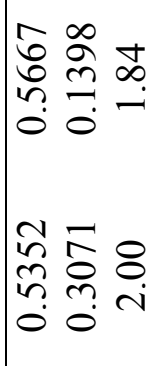 & 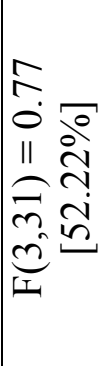 & 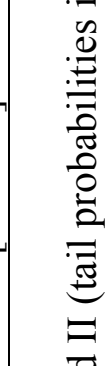 \\
\hline & 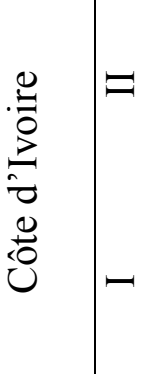 & 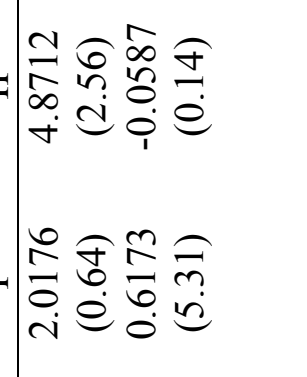 & 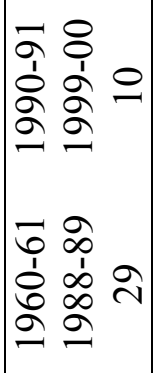 & 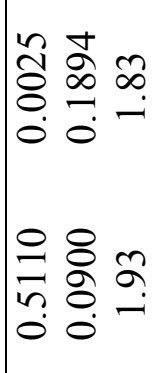 & 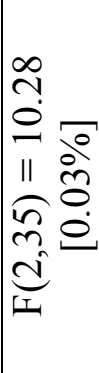 & 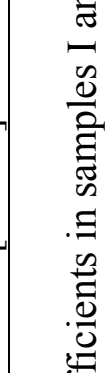 \\
\hline & $=$ & 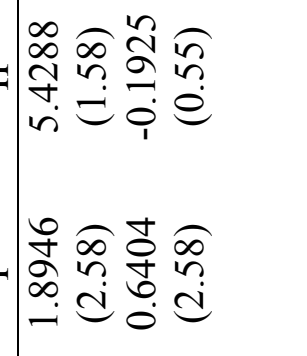 & 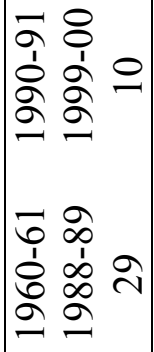 & 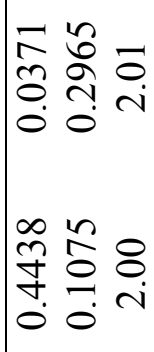 & 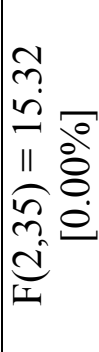 & 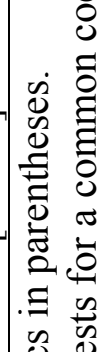 \\
\hline & 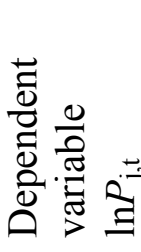 & 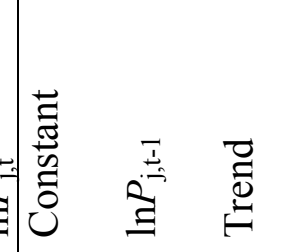 & $\begin{array}{l}0 \\
0 \\
0 \\
0 \\
0 \\
0 \\
0 \\
0 \\
0 \\
0 \\
0\end{array}$ & N & 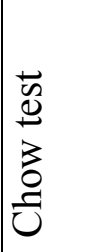 & 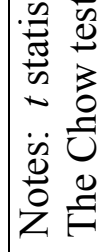 \\
\hline
\end{tabular}




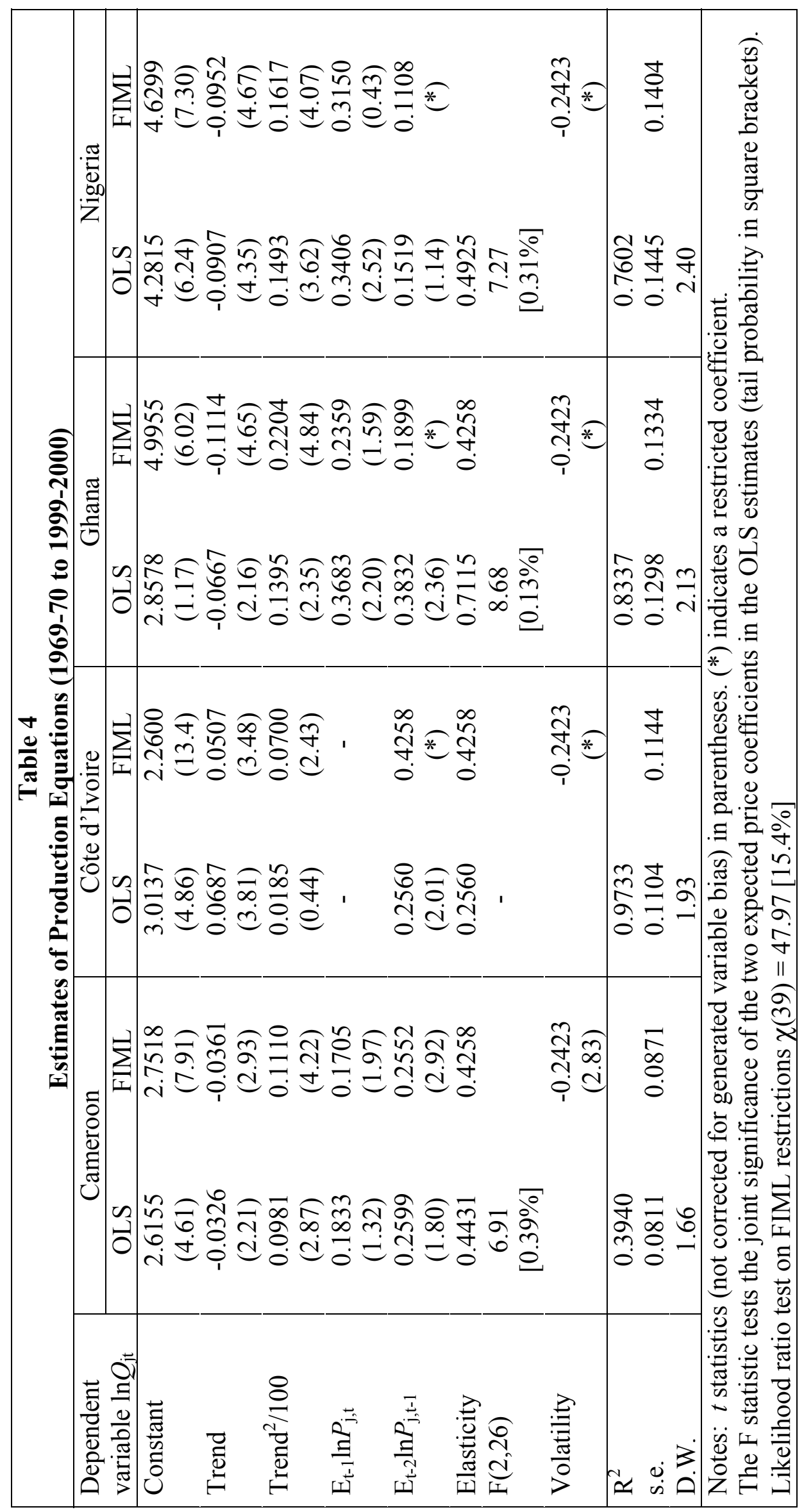




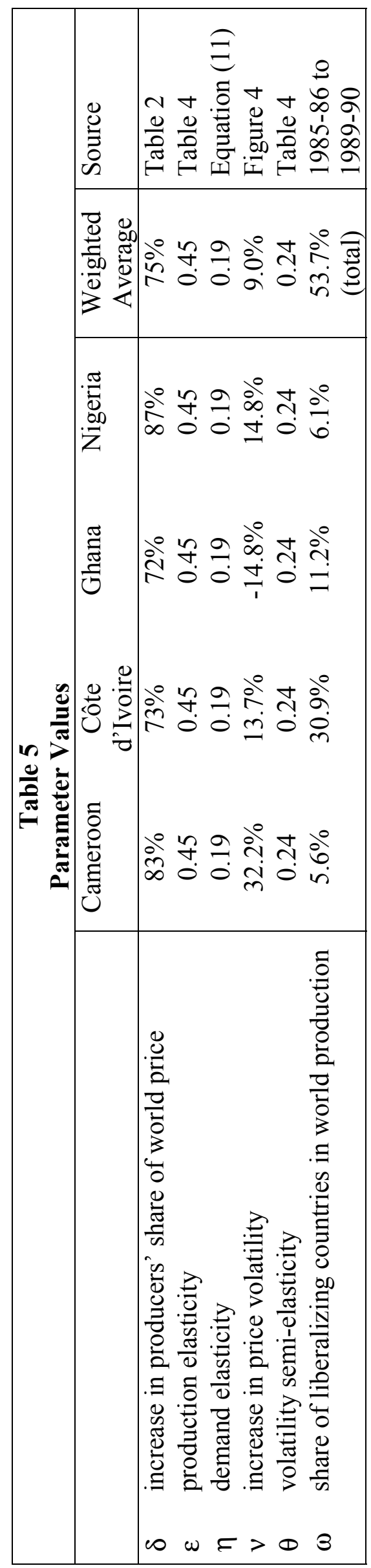

\begin{tabular}{|c|c|c|c|}
\hline & 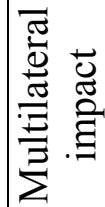 & 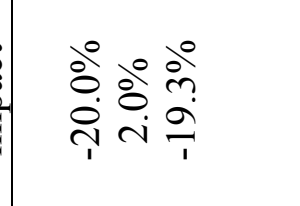 & \\
\hline 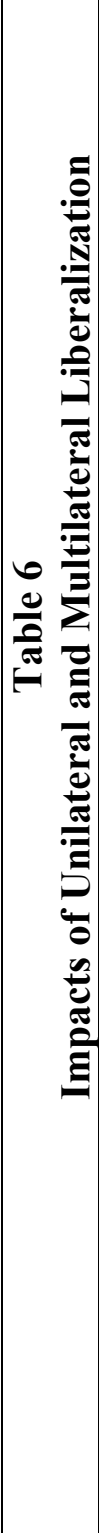 & 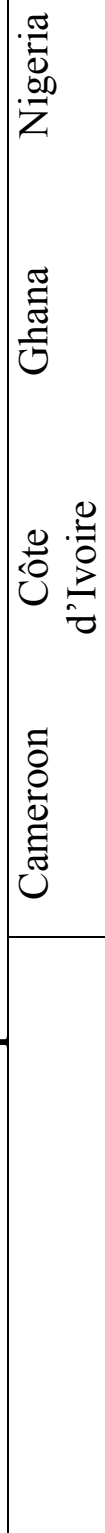 & 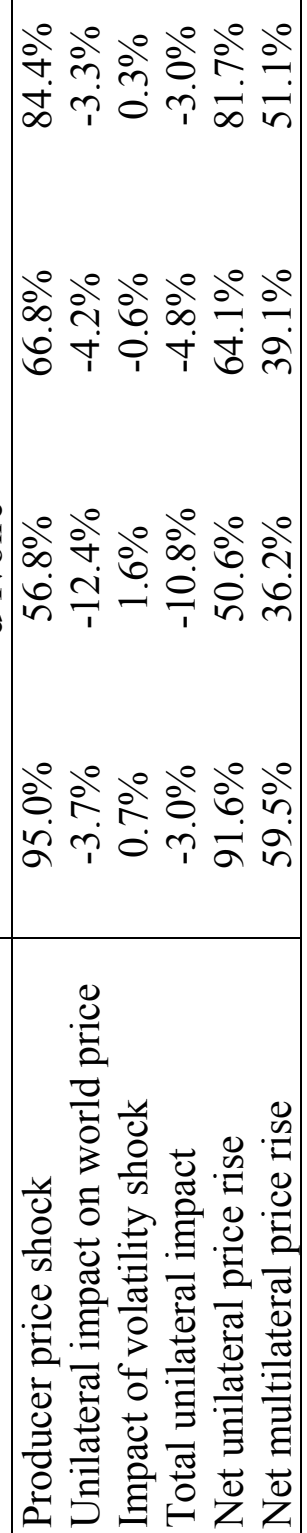 & 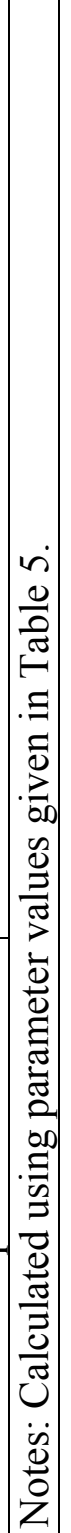 \\
\hline
\end{tabular}



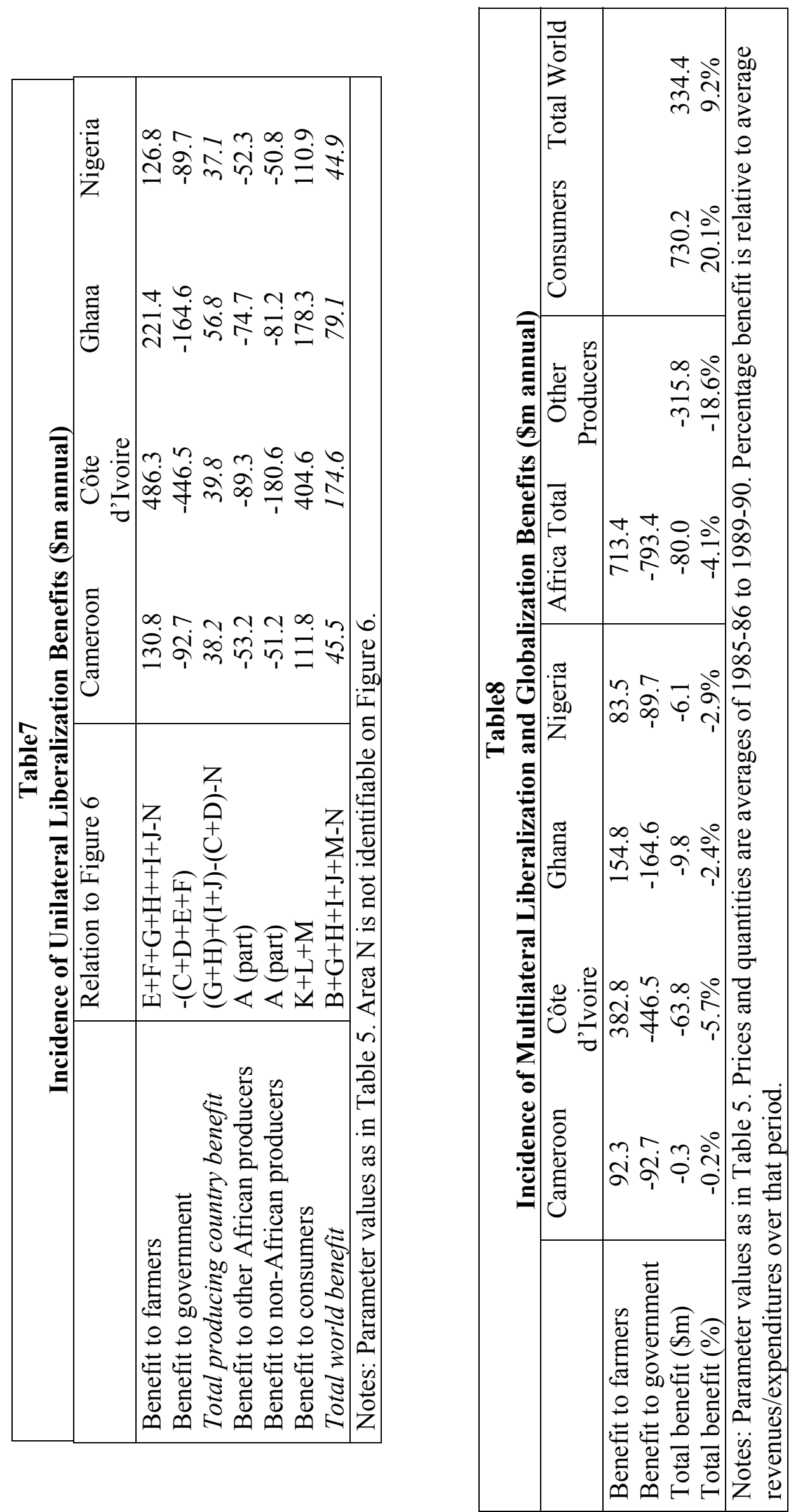


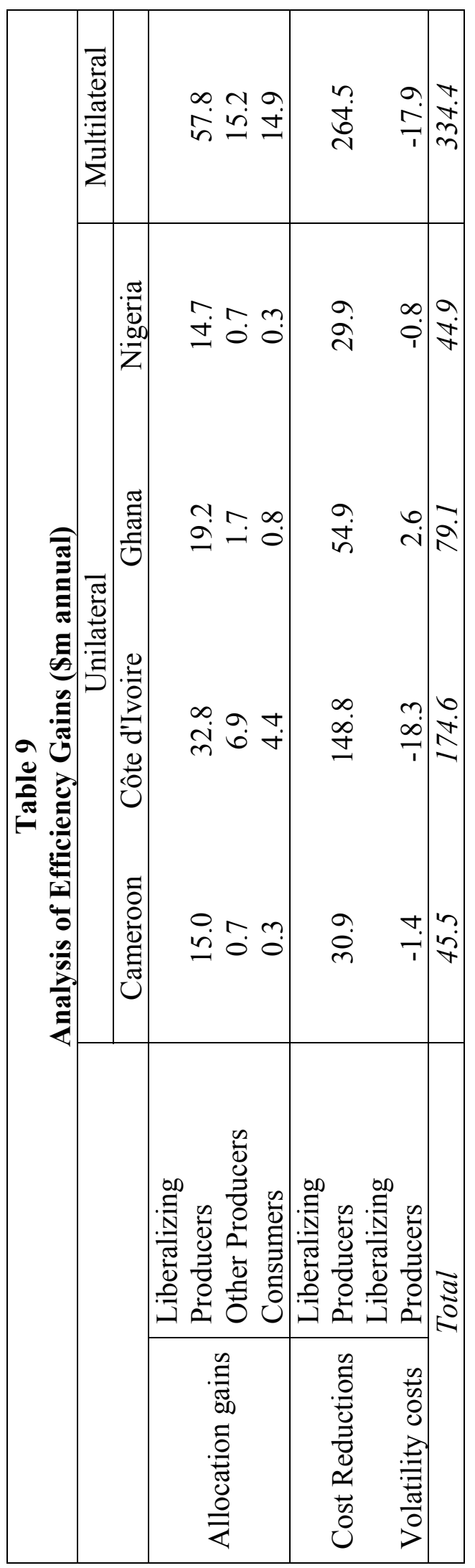

n 


\section{References}

Akiyama, T., J. Baffes, D. Larson and P. Varangis (2001), "Market reforms: lessons from country and commodity experiences", chapter 1 of Akiyama, T., J. Baffes, D. Larson and P. Varangis, Commodity Market Reforms: Lessons from Two Decades. Washington DC, World Bank.

Akiyama, T., and D. Larson (1994), "The adding-up problem: strategies for primary commodity exports in sub-Saharan Africa", Policy Research Paper 1245, Washington DC, World Bank.

Bates, R.H. (1989), "Structural adjustment and agriculture", in S. Commander ed., Structural Adjustment and Agriculture: Theory and Practice in Africa and Latin America, London, Overseas Development Institute.

Bhagwati, J. (1958), "Immiserizing growth: a geometrical note", Review of Economic Studies, 25, 201-5.

Engberg-Pederson P. et al. (1996), eds. Limits of Adjustment in Africa: The Effects of Economic Liberalization, 1986-94, Copenhagen: Centre for Development Research, Portsmouth, N.H., Heinemann.

Evenson, R.E. (2002), “Technology and prices in agriculture”, manuscript, New Haven, Yale University.

Gilbert, C.L. (1987), “International commodity agreements: design and performance”, World Development, 15, 591-616.

Gilbert, C.L. (1996) "International commodity agreements: an obituary notice”, World Development, 24, 1-19.

Gilbert, C.L. (1997), Cocoa Market Liberalization, London, Cocoa Association of London.

Gilbert, C.L. (2002), “Commodity risk management: preliminary lessons from the International Task Force", chapter 2 of Garnault, R. ed., Resource Management in Asia Pacific Developing Countries, Canberra, Asia Pacific Press.

Gilbert, C.L., and E. Tollens (1999), "Effets de la libéralisation dans les sous-secteurs café-cacao au Cameroun”, report for the European Commission (Volume 1), Yaoundé, European Commission.

Gilbert, C.L., and E. Tollens (2002), “Does market liberalization jeopardize export quality? Cameroonian cocoa, 1985-2000”, CEPR Discussion paper 3224. 
Gilbert, C.L. and J. ter Wengel (2001), "The production and marketing of primary commodities", in Common Fund for Commodities, Commodities and Development at the Turn of the Millennium, Amsterdam, Common Fund for Commodities, 21-62.

Johnson , H.G. (1953), "Equilibrium growth in an expanding economy", Canadian Journal of Economics and Political Science, 19, 478-500.

Johnson, H.G. (1958), International Trade and Economic Growth, London, George Allen and Unwin.

Kanbur, S.M.R. (1984), "How to analyse commodity price stabilisation: a review article", Oxford Economic Papers, 36, 336-58.

Krishna, K. (1993), “The Adding-up Problem: A Targeting Approach”, manuscript, Pennsylvania State University.

McIntire, J., and P. Varangis (1999), "Reforming Cote d'Ivoire's Cocoa Marketing and Pricing System", World Bank Policy Research Working Paper, No. 2081, March.

Mosley, P., J. Harrington and J. Toye (1991), Aid as Power: The World Bank and Policy-Based Lending, London, Routledge.

Newbery, D.M.G. and J.E. Stiglitz (1981), The Theory of Commodity Price Stabilization, Oxford, Clarendon Press.

Oi, W.Y. (1961), "The desirability of price instability under perfect competition", Econometrica, 29, 58-64.

Pagan, A.R. (1984), "Econometric issues in the analysis of regressions with generated regressors", International Economic Review, 25, 221-47.

Paxson, C. (1993), "Consumption and income seasonality in Thailand", Journal of Political Economy, 101, 39-72.

Ruf, F., and H. de Milly (1990), "Comparison of cocoa production costs in seven producing countries", paper presented at ICCO Advisory Group on the World Economy, seventh meeting, Accra, Ghana, June 18-20 1990.

Schiff, M. (1994), "Commodity Exports and the Adding-up Problem in Developing Countries: Trade, Investment, and Lending Policy", Policy Research Working Paper 1338, Washington DC, World Bank. 
Varangis, P., and G. Schreiber (2001), "Cocoa market reforms in west Africa", chapter 2 of Akiyama, T., J. Baffes, D. Larson and P. Varangis, Commodity Market Reforms: Lessons from Two Decades. Washington DC, World Bank.

Williams, G. (1985), "Marketing with and without marketing boards", Review of African Political Economy, 34, 4-15.

World Bank (1994), Adjustment in Africa, New York, Oxford University Press. 